\title{
TOURISM POTENTIAL OF GIEŁCZEWSKA ELEVATION (CENTRAL-EASTERN POLAND) Tourism potential of Giełczewska Elevation
}

\author{
TERESA BRZEZIŃSKA-WÓJCIKㄹ, ANDRZEJ ŚWIECA²
}

\author{
1 The Maria Curie-Skłodowska University in Lublin, Institute of Earth Sciences, \\ Department of Regional Geography and Tourism \\ 2 The Josef Pilsudski University of Physical Education in Warsaw, Faculty of Physical \\ Education and Sport in Biata Podlaska, Chair of Tourism and Recreation
}

\author{
Mailing address: Teresa Brzezińska-Wójcik, Maria Curie-Skłodowska University, Department \\ of Regional Geography and Tourism, 2cd Kraśnicka Ave., 20-718 Lublin, tel.: +48 81 5376851, \\ fax: +48 81 5376862, e-mail: tbrzezin@poczta.umcs.lublin.pl
}

\begin{abstract}
Introduction. This study attempts to assess the tourism potential (natural resources of the geographical environment, cultural resources and tourism infrastructure) of Giełczewska Elevation. Material and methods. Based on research conducted in six municipalities, including one urban-rural (Piaski) and five rural (Jabłonna, Wysokie, Krzczonów, Żółkiewka, Rybczewice) the factors affecting the characteristics of tourist space of Giełczewska Elevation were examined. Using 48 features, grouped in four sections (tourist values, recreational and specialist qualities, tourist management, environment condition) the tourist potential of municipalities was assessed. It was expressed by synthetic numerical values of tourist attractiveness measures specified for each municipality. Results. Calculated using the method of multidimensional comparative analysis, the synthetic indices of tourist attractiveness ranged from 0.18 (Wysokie) to 0.47 (urban-rural Piaski). Their volume was significantly affected by characteristics of the group of recreational and special qualities and tourist management. Much less important were qualities of sightseeing, while the smallest - the condition of the environment. Conclusions. In view of the measures obtained, the tourism potential of Giełczewska Elevation values shapes the diverse recreational, specialist and sightseeing, and considerably varying tourist management. Less important is the environment.
\end{abstract}

Key words: tourist potential, municipalities: Piaski, Jabłonna, Wysokie, Krzczonów, Żółkiewka, Rybczewice

\section{Introduction}

Natural resources of the geographical environment are, in addition to cultural resources and tourist infrastructure, an essential element of tourism potential, which determines the attractiveness of tourist spatial units [1]. The attempts made so far to assess the tourist potential differ in spatial scope, methods of development and approach. Studies refer to the cities [2, 3], selected regions $[4,5,6,7,8]$, and even the whole country [9].

This study covers a fragment of Lubelsdkie Voivodeship, within the borders of the town and municipality Piaski and rural municipalities: Jabłonna, Wysokie, Krzczonów, Żółkiewka, Rybczewice. Analyzed municipalities occupy a total of $771.7 \mathrm{~km}^{2}$ (3.1\% of the Lublin Voivodeship) and cover 37963 persons (1.8\% population of the Voivodeship). Population density is 48 persons per $\mathrm{km}^{2}$, and is almost two times lower than in Lubelskie (86 persons $/ \mathrm{km}^{2}$ ) [10]. In physical-geographical terms the municipalities are located in the Lublin Upland and Roztocze [11]. The dominant part of the land they cover are mezoregion Giełczewska Elevation and to a lesser extent - Zamojski Basin and Świdnicki Plateau. A small southern part of the analyzed area, within municipality Wysokie, enters the mezoregion of West Roztocze (Fig. 1). The highest point (Boży Dar in municipal- ity Krzczonów) reaches $306.0 \mathrm{~m}$ over the sea level. Minimum height $(170.0 \mathrm{~m})$ has been recorded in the valley in the Giełczew Valley and municipality Piaski. Extreme de-levelling is $123.6 \mathrm{~m}$ (in municipality Krzczonów).

The ground of the studied area is dominated by Upper Cretaceous limestone (limestone, opokas) covered locally by the Palaeogene (gaize) and Neogene sediments (sands and sandstones). Surface formations, mostly of Quaternary age, are formed by a complex of sediments, differing in genetic and stratigraphic respects (silt-clays, fluvioglacial sands and gravels, loess formations, sands and silts with the river-periglacial gravels). The youngest sediment series - formations of Holocene - is represented by the valley formations (fluvial sands and river gravels) and slope silts.

The area of municipalities: Wysokie, Krzczonów, Żółkiewka, Rybczewice and Piaski are drained by the left tributaries of Wieprz - Por, Żółkiewka and Giełczew. Municipality Jabłonna is located within the system of Bystrzyca. It is drained by its two tributaries - Czerniejówka and Kosarzewka. In the river valleys the inventory of water phenomena is enriched by springs and ponds. Large concentration of springs can be seen in the Giełczew valley, in municipality Rybczewice and municipality Wysokie, in Giełczew town. The most efficient springs (over 178 
l/s) are concentrated in Stryjno, municipality Rybczewice. The ponds occur in Czerniejówka valley in Jabłonna, Giełczew valley in Piaski and Częstoborowice and Żółkiewka valley in Żółkiewka. In total, they take $1.8 \%$ of their area of municipalities analyzed and play the retention and cultivation roles.

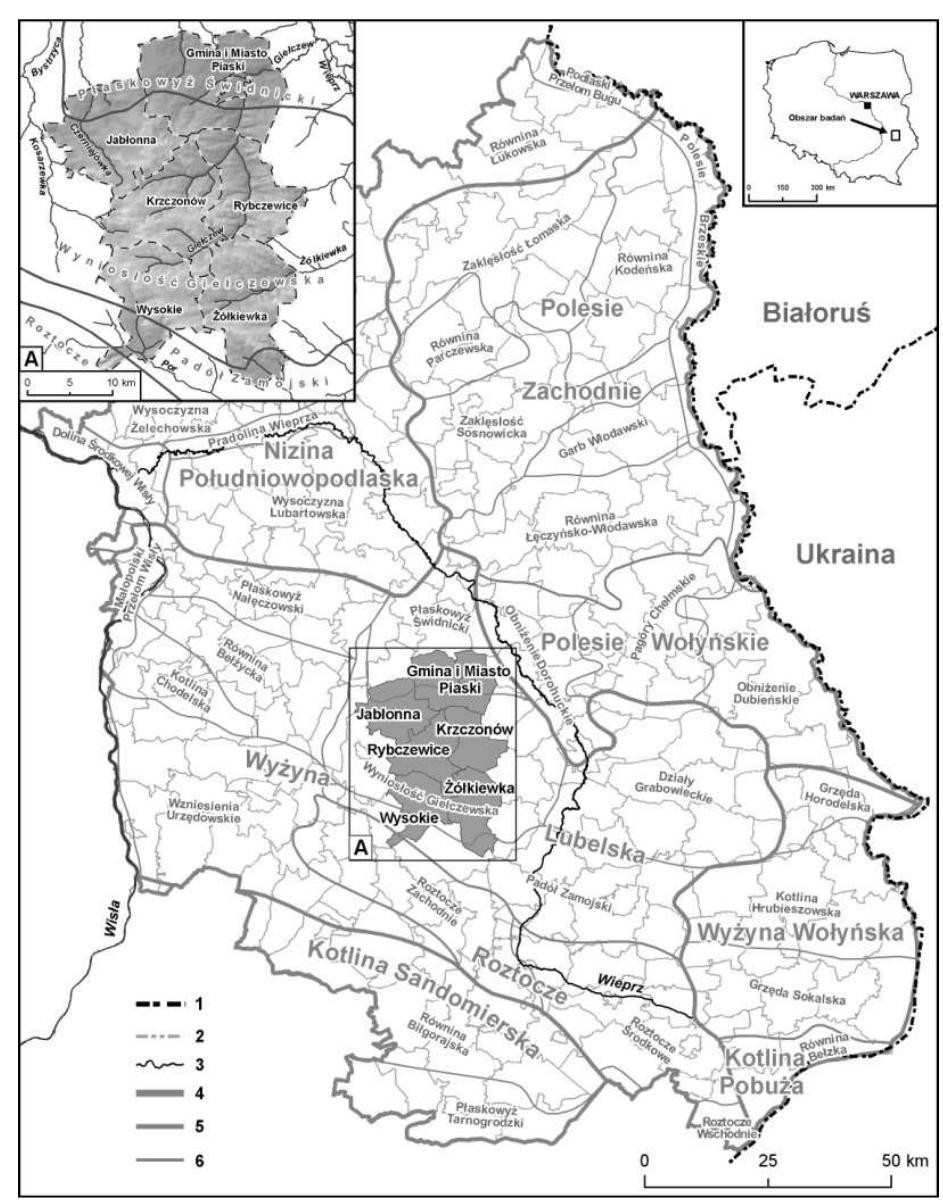

Key: A - Landform features of the municipalities under study based on Digital Elevation Model (DEM). 1 - state borders; 2 - municipialities borders; 3 rivers; 4 - boundaries of physiographic sub-provinces; 5 - boundaries of physiographic macroregions; 6 - boundaries of physiographic mesoregions

Figure 1. Location of the municipalities under study against the physiographic division of Poland (according to Kondracki and Richling [11])

In terms of the climatic conditions, the area of analyzed municipalities is distinguished by a relatively high volume of precipitation (500-600 $\mathrm{mm}$ ) and the highest values of relative sunshine rate during the summer (45-59\%). It is characterized, in comparison to neighbouring areas, by extended duration of the summer season (96-98 days) [12].

In the structure of land use - the farmlands dominate. They account for $83 \%$ of the analyzed area, including as much as $77 \%$ of arable land. Farms have a very high fragmentation rate - an average of about $60 \%$ are the farms with an area of not more than 5 hectares [13]. Forests and forest lands constitute about $11 \%$ of the analyzed area [10]. Large forested areas are preserved in the municipalities Jabłonna, Krzczonów and Wysokie.

The aim of this study was to examine the impact of natural and cultural resources and tourist facilities on the shaping of tourism potential of Giełczewska Elevation in Lubelskie Voivodeship.

\section{Material and methods}

Information about tourist attractions, tourism development and condition of the environment in selected municipalities of Giełczewska Elevation was collected during field studies (inventory tours), and based on secondary sources (registers, statistical yearbooks, maps, reports on the condition of the environment, textbooks and scientific publications). Summary of natural of sightseeing and recreational and specialized values was performed using classification of Lijewski et al. [22]. And touring cultural values were analyzed taking into account the kind classification, based on the instructions of the Main Board of PTTK. The characteristics of tourist infrastructure have been developed according to the classification of Rogalewski [14] and Gołembski [15], and the environment condition - with consideration of the work of Gołembski [15]. The research procedure highlights the several stages which have been described in detail in the paper "Tourist resources and their use in the town and municipality of Nałęczów and municipality of Wojciechów" [7].

\section{Results}

Numerical values of the overall tourist attractiveness measure (Fig. 2) indicate that the highest attractiveness is characteristic for the municipality Piaski (0.47), and the smallest - municipality Wysokie (0.18). In other municipalities, this ratio is as follows: 0.35 - Krzczonów, 0.32 - Rybczewice, 0.31 - Żółkiewka, 0.29 - Jabłonna. The numerical measures were influenced by the environmental elements, expressed primarily in the recreational and special values and tourism infrastructure. Less important were the qualities of sightseeing, while the smallest - the condition of the environment.

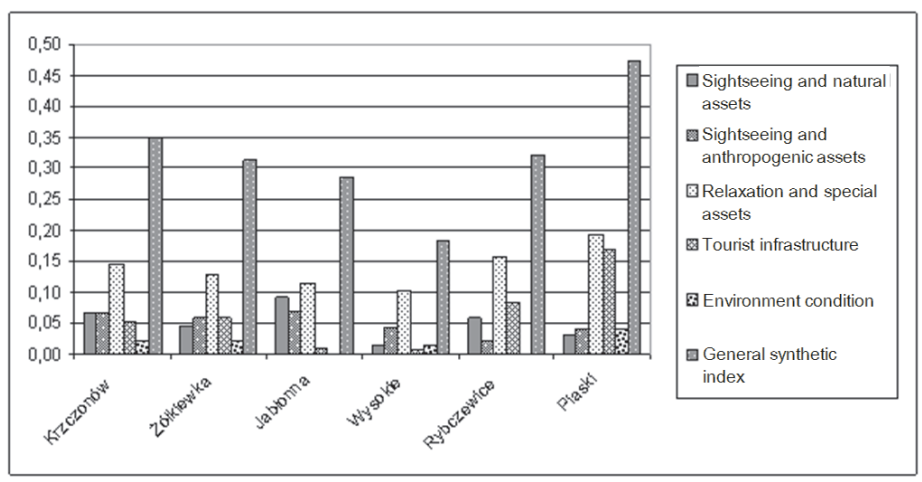

Figure 2. Synthetic tourist attractiveness index for the Giełczew Elevation municipalities, including its constituent divisions

\section{Relaxation and special values}

The recreational and special values covered nine features, including seven from the group of recreational values. The characteristics taken into account referred to the proposal of Sołowiej [16] and Wyrzykowski [17] and included hypsometric relations, land cover (forested, grassland, other and wasteland), areas of stagnant water and the purity of surface waters. In the municipalities studied, numerical measure for this part were set out in the range from 0.19 (Piaski) to 0.10 (Wysokie). Numerical values of the meter accounted for about $40 \%$ of the numerical value of the attractiveness synthetic index in municipalities Jabłonna, Żółkiewka, Piaski and Krzczonów; in Rybczewice it was 49\%, and municipality Wysokie - about 56\% (Tab. 1). 
Table 1. Synthetic tourist attractiveness index for the Giełczew Elevation municipalities, including its constituent divisions

\begin{tabular}{|c|c|c|c|c|c|c|c|c|c|c|c|c|c|c|}
\hline \multirow{3}{*}{ Division } & \multicolumn{10}{|c|}{ Municipalities } & \multirow{2}{*}{\multicolumn{2}{|c|}{$\begin{array}{c}\text { Town and Municipali- } \\
\text { ty Piaski }\end{array}$}} & \multirow{2}{*}{\multicolumn{2}{|c|}{$\begin{array}{l}\text { Synthetic index for } \\
\text { divisions }\end{array}$}} \\
\hline & \multicolumn{2}{|c|}{ Krzczonów } & \multicolumn{2}{|c|}{ Żółkiewka } & \multicolumn{2}{|c|}{ Jabłonna } & \multicolumn{2}{|c|}{ Wysokie } & \multicolumn{2}{|c|}{ Rybczewice } & & & & \\
\hline & $\begin{array}{l}\text { synthetic } \\
\text { index }\end{array}$ & {$[\%]$} & $\begin{array}{l}\text { synthetic } \\
\text { index }\end{array}$ & {$[\%]$} & $\begin{array}{l}\text { synthetic } \\
\text { index }\end{array}$ & {$[\%]$} & $\begin{array}{l}\text { synthetic } \\
\text { index }\end{array}$ & {$[\%]$} & $\begin{array}{l}\text { synthetic } \\
\text { index }\end{array}$ & {$[\%]$} & $\begin{array}{l}\text { synthetic } \\
\text { index }\end{array}$ & {$[\%]$} & $\begin{array}{l}\text { synthetic } \\
\text { index }\end{array}$ & {$[\%]$} \\
\hline $\begin{array}{l}\text { Sightseeing and } \\
\text { natural assets }\end{array}$ & 0.07 & 19.0 & 0.05 & 15.1 & 0.09 & 32.1 & 0.01 & 8.1 & 0.06 & 18.6 & 0.03 & 6.6 & 0.31 & 16.1 \\
\hline $\begin{array}{l}\text { Sightseeing and } \\
\text { anthropogenic } \\
\text { assets }\end{array}$ & 0.06 & 18.6 & 0.06 & 19.1 & 0.07 & 24.3 & 0.04 & 22.9 & 0.02 & 6.5 & 0.04 & 8.7 & 0.30 & 15.5 \\
\hline \begin{tabular}{|l} 
Relaxation and \\
special assets
\end{tabular} & 0.15 & 41.7 & 0.13 & 40.7 & 0.11 & 39.9 & 0.10 & 55.9 & 0.16 & 48.8 & 0.19 & 40.7 & 0.84 & 43.6 \\
\hline Tourist infrastructure & 0.05 & 15.0 & 0.06 & 18.7 & 0.01 & 3.7 & 0.01 & 4.6 & 0.08 & 26.1 & 0.17 & 35.6 & 0.38 & 19.9 \\
\hline \begin{tabular}{|l|}
$\begin{array}{l}\text { Environment condi- } \\
\text { tion }\end{array}$ \\
\end{tabular} & 0.02 & 5.7 & 0.02 & 6.4 & 0.00 & 0.0 & 0.02 & 8.5 & 0.00 & 0.0 & 0.04 & 8.4 & 0.10 & 4.9 \\
\hline \begin{tabular}{|l|} 
General synthetic \\
index
\end{tabular} & 0.35 & 100.0 & 0.31 & 100.0 & 0.29 & 100.0 & 0.18 & 100.0 & 0.32 & 100.0 & 0.47 & 100.0 & & 100.0 \\
\hline
\end{tabular}

It was found that in the municipalities analyzed the greatest impact on the value of numerical measures had the water phenomena, the hypsometric relationship and afforestation. It was particularly clearly marked in the case of Piaski and Rybczewice municipalities. In the municipality Piaski the highest rate of synthesis was set (0.13) for surface of stagnant waters. Also in the municipality Piaski, and in the municipality Rybczewice relatively high rate was obtained for the feature of the purity of rivers and stagnant water (in both municipalities 0.09). The presence of water, its cleanliness is important for recreational purposes. Flowing and standing waters significantly increase tourist attractiveness, contributing positively to the scenic qualities of the landscape. The numerical values meter was also affected by recreational forest areas (respectively 0.08 in the municipality Piaski and 0.07 in the municipality Rybczewice). Forest ecosystems of the studied area had a large proportion of hornbeam forests. Forest surfaces increase the recreational attractiveness of the area. They contribute to the reduction of wind speed and suppress noise. They purify the air by absorbing heavy metals harmful for the organisms [18].

Among the characteristics which increase the recreational value also the climatic conditions are taken into consideration $[19,20]$. The practice of all forms of outdoor recreation is set by the general recreational season, identified with the period of plant vegetation. In the municipalities studied its length is on average 210-220 days per year [17]. Narrower concept of the general recreational season is the bathing season, which is marked by the period between the average long-term appearance and disappearance of water temperature above $18{ }^{\circ} \mathrm{C}$ [21]. At the studied site it takes 50-80 days [20].

In the studied area the optimum period of the use of the landscape during the warm season, set from the beginning of the spring to the end of autumn, is the longest in Lubelskie Voivodeship scale and lasts an average of 140-150 days. The length of the winter use of natural environment, identified with the period of snow cover [20] in the analyzed municipalities takes on average 70-75 days per year [12]. Much shorter is the length of ski trips (less than 40 days). The evaluation of winter sports opportunities is also related to the period of icing water. Its length determines the time during which the skating is practiced, or ice boat sports. Optimal ice sports period is usually shorter by the average of 20 days in the municipalities analyzed than in the rest of the Lubelskie Voivodeship [22].

Direct human environment is shaped by the group of physical, chemical, biological and meteorological conditions, known as bioclimatic conditions [23]. The main meteorological factors analyzed in this respect are the real sunshine, cloudiness, air temperature, sultriness, wind, precipitation, snow, fog and storms [24].

The value of real sunshine for the purposes of tourism and recreation should exceed 1500 hours per year [23]. The studied area in this respect is privileged (1560 hours per year). But the influx of solar radiation in the studied municipalities is neutralized by a considerable degree of cloudiness (65\%) per year [12], which causes that the conditions for heliotherapy are average.

The most tangible climatic stimulus, which is the basic bioclimatic criterion are the thermal conditions. Beneficial effects on the human body are noted on days with average daily temperatures of $18-22^{\circ} \mathrm{C}$. In the municipalities studied, this period lasts an average of 40 days a year. It turns out that temperature variation from day to day has greater impact on the human body than its value. The daily changes of temperature in the analyzed area (1.9-2.0 ${ }^{\circ} \mathrm{C}$ ) are undetectable by the human body [19].

A characteristic feature of the research area is the large share of atmospheric silences (23\%) and days with weak winds $(<2 \mathrm{~m} / \mathrm{s})$ [12]. An important indicator of climate inventiveness is precipitation. Average number of days with precipitation is 155 and it is smaller than the accepted standards for spas (183 days) $[12,25]$.

Limiting factors are the fog and storms, but they do not play a significant role in bioclimatic shaping of the analyzed municipalities. The frequency of fog deposition does not exceed the accepted norm (38 days) for the village of climate valour [19].

\section{Tourist infrastructure}

Attractiveness indicator set for tourist infrastructure gained a relatively large size in the municipalities Piaski $(0.17)$ and Rybczewice (0.08) (Tab. 1). The impact mainly involved quite extensive accommodation, as for the rural conditions. In Piaski municipality there is a total of 49 beds ( 1 inn and 3 agritourism farms) and municipality Rybczewice 10 beds (1 agritourism farm).

An important element increasing the attractiveness of reception areas of both municipalities was also the availability of transport. Municipalities stand out in terms of length of roads. The network of paved roads (four categories: national, voivodeship, poviat and municipal roads) in the municipality Piaski has a total length of $234 \mathrm{~km}$, of which $24-\mathrm{km}$ section falls on the road of national importance. Rybczewice municipality has a longer than Piaski network of roads - $253 \mathrm{~km}$, but up to $62.9 \%$ with unpaved surface. Availability of transport in both municipalities is complemented by the technical and service facilities of trans- 
port in the form of car parks, gas stations and vehicle service station.

In terms of nutritional database the widest range of services is offered by the municipalities Krzczonów and Piaski. In the municipality Piaski 13 catering outlets primarily located in the town of Piaski operate there. The structure of catering is dominated by restaurants and bars (total of 8 facilities). Krzczonów municipality has eleven catering facilities, mainly in the form of seasonal food and beverage outlets (5), restaurants (3), fast food (2) and confectionery shops (1).

\section{Sightseeing and natural values}

Natural aspect ranks high in cognitive tourism. The sightseeing values include 21 features, in these 14 properties in the group of natural values. The calculated size of numerical measures for this part of the synthetic division features indicate that the values of nature tours have a significant impact on the overall measure of attractiveness especially in the municipalities Krzczonów and Jabłonna.

Among natural elements, in the municipality Jabłonna there are important peculiarities of flora and fauna represented by the localities of rare plants (e.g. Turk's cap lily), monumental trees and nature reserves ("Chmiel", "Olszanka") (synthetic index 0.07) and scenic parks with buffer zone (0.06, Krzczonowski Landscape Park). A characteristic element of the natural values of municipality Jabłonna are historic parks. One of the two, adjacent to the closed to visitors the park of eclectic system in Jabłonna, is an accessible park near the manor in Tuszów. Parks provide a synthetic indicator of 0.03 . In the group of natural values the sightseeing viewpoints are also noteworthy.

However, in the municipality Krzczonów, in the group of natural assets, the highest rate (0.05) was received by springs. Of the ten springs inventoried, two - are legally protected (Piotrkówek and Walentynów). Groundwater flows are very picturesque and are linear, they are often fissured-layer and pulsating flows. Large impact on the attractiveness of natural municipalities also has a group of gorges, gapes, river valleys with indicator 0.03. A narrow ( $0.5 \mathrm{~km}$ wide) Giełczew valley in the southern part of the municipality forms a picturesque gape in Wola Sobieska.

\section{Sightseeing and cultural assets}

The biggest impact on the overall measure of attractiveness of anthropogenic values had the municipalities Jabłonna (0.07) and Wysokie (0.04).

In both municipalities there are important historical monuments, represented by the monuments of architecture and urbanism and technical monuments. In the group of monuments of architecture and urbanism the most numerous are the religious facilities and systems (municipality Wysokie - 5, and municipality Jabłonna - 4) and farm buildings (in the municipality Jabłonna - 3). Technical monuments are represented by two hydro and wind structures (in the municipality Jabłonna it is a quite ruined post mill, and in the municipality Wysokie - wooden mill built in 1928).

\section{Environment condition}

In determining the opportunities for recreation in the area, a decisive role is played by environmental cleanliness and the ongoing care of its current condition. Measures for environmental protection include: concern for waste management, attention to the state of air pollution and noise level. To assess the degree of air pollution in the municipalities studied, the data of the Voivodeship Inspectorate of Environment Protection were used. Analyzed pollutants (SO2, NO2, particulate matter) did not exceed the general acceptable standards. The comfort of relaxa- tion and regeneration in the open air is also determined by the noise level. The main source of traffic noise is road traffic, particularly in the municipality Piaski, on national road E372. The noise level along this road is approximately $71 \mathrm{~dB}$, and slightly exceeds the norm (60-70dB). In the vicinity of the town Piaski, the residents are protected by noise screens of 1.8 kilometres in length [26]. Voivodeship road No. 835 passes through municipalities Jabłonna and Wysokie. Traffic on it is not large enough for the noise to be bothersome. In other municipalities: Krzczonów, Żółkiewka and Rybczewice road traffic is not a risk of noise pollution.

In view of the attractiveness analysis of the research area in the environmental respect, the municipality Piaski (0.04) is most advantageous. Synthetic indices obtained for municipalities Krzczonów, Żółkiewka and Wysokie are twice lower (Tab. 1). However, in the municipalities Jabłonna and Rybczewice environment purity has a very limited impact on tourism development.

\section{Discussion}

In view of the calculated measures of attractiveness of six municipalities (Piaski, Jabłonna, Wysokie, Krzczonów, Żółkiewka, Rybczewice) it can be said that the tourism potential of Giełczewska Elevation shows considerable variations. The calculated value of the synthetic numerical measure of attractiveness in the surveyed municipalities range from 0.18 (Wysokie municipality) to 0.47 (municipality Piaski). In other municipalities these measures are: 0.29 (Jabłonna), 0.31 (Żółkiewka), 0.32 (Rybczewice), 0.35 (Krzczonów).

The results showed that the value of the synthetic index was affected primarily by recreational values (43.6\%) and tourist infrastructure (19.9\%), followed by sightseeing and natural values $(16.1 \%)$ and cultural values $(15.5 \%)$ and the least - condition of the environment $(4.9 \%)$.

In the comprehensive assessment of the factors influencing the tourism potential, an important role is played by the landscape assets. It is quite commonly assumed that the aesthetic qualities of landscape are the essential values of recreation, and the presence of a particular type of landscape is a basic condition for the development of tourism $[17,27,28]$. In the literature [17, $18,29,30,31]$ the assessment of the landscape in terms of tourism is based largely on the analysis of terrain, forms of land use, habitat types of forests, water phenomena.

In view of the studies it was found that among the recreational values tourism potential of municipalities is determined by forest complexes (Jabłonna), ponds (Piaski), significant delevelling (Krzczonów), good condition of cleanliness of rivers and stagnant water (Krzczonów, Żółkiewka, Rybczewice and Piaski). A significant part in shaping of the analyzed area include the elements of tourist infrastructure, especially road transport accessibility, catering and associated base (in all municipalities) and accommodation in only three municipalities: Piaski, Rybczewice and Wysokie. Among the advantages of natural sightseeing the impact on the attractiveness of the area have the flora peculiarities (in all municipalities), scenic parks (Jabłonna, which entire surface is covered by legal protection - Krzczonowski Landscape Park and Czerniejewski Protected Landscape Area), the Giełczew valley (Żółkiewka), springs (Krzczonów), historic parks (Piaski and Rybczewice), numerous viewing points (Jabłonna). Among the cultural values, tourism potential is shaped by historical monuments and cultural events (in all municipalities), facilities and centres of popular culture (in the municipalities Jabłonna and Wysokie), archaeological facilities (in the municipality Krzczonów) as well as museums, archives and collections (in the town and municipality Piaski). 
Diversification of tourism potential of the municipalities analyzed are also confirmed by the results of Tucki's research [32]. The author studied the tourist potential of the Lubelskie Voivodeship (in his study he considered 209 municipalities). In the assessment of potential he took into account tourist resources, tourism and para-tourism infrastructure and the availability of transport. These data served the author to calculate the synthetic index of tourism attractiveness. The results obtained allowed the respondents to rank the municipalities by degree of attractiveness, and use of attractiveness classes - to group them in terms of tourist value presented (he separated four groups of municipalities: very attractive - 28 municipalities, attractive - 60 municipalities, averagely attractive - 93 municipalities, unattractive - 28 municipalities). In the study of Tucki [32], according to the synthetic index of tourism attractiveness, municipalities Rybczewice and Piaski were classified as attractive, Krzczonów and Jabłonna - as averagely attractive, and Żółkiewka and Wysokie - unattractive.

\section{Conclusions}

Wide variety of recreational and special, and sightseeing, as well as significant differentiation in the tourist infrastructure components makes the area of analyzed municipalities ready for various forms of tourism: cognitive (nature, geotourism, ecotourism), recreation (agritourism) and qualified tourism (walking, cycling, cross-country skiing). The high quality of the environment, particularly satisfactory condition of municipalities in the field of wastewater treatment (Krzczonów and Żółkiewka) and waste management (Piaski) is also worth emphasizing.

\section{Literature}

1. Świeca, A. \& Tucki A. (2009). Attractiveness as a reflection of the values in the geography of tourism. In G. Janicki \& M. Łanczont (Eds.), Geography and values (pp. 229-241). Lublin: Wydawnictwo UMCS. [in Polish]

2. Bellinger, C. (1994). Tourist potentials of the city. TrendsForschung-Koncepte im Strategischen Turismusmanagment. Band 4, Trier. [in German]

3. Zajadacz, A. (2004). Tourism Potential of Cities on the Example of Selected Cities of the Western Sudetes. Warszawa: Bogucki Wydawnictwo Ekonomiczne. [in Polish]

4. Latosińska, J. \& Włodarczyk B. (2004). Lakeland Slavskie tourist potential. Turyzm 14(1), 75-89. [in Polish]

5. Milewski, D. (2004). Regional Determinants of Tourism Development on the Example of the Zachodniopomorskie Voivodeship. Szczecin: Wydawnictwo Naukowe Uniwersytetu Szczecińskiego. [in Polish]

6. Skrzypczak, A. \& Chmielewska A.B. (2009). Tourist potential of Janów Podlaski municipality and assessment of its attractiveness compared to Poviat Bialski. Annales UMCS sec. B 64(1), 201-211. [in Polish]

7. Świeca, A. \& Brzezińska-Wójcik T. (2009). Tourism resources and their use in the city and municipality Nałęczów and municipality Wojciechów. Annales UMCS sec. B 64(1), 141-166. [in Polish]

8. Włodarczyk, B. (2003). Tourist potential. In S. Liszewski (Ed.), Opportunities and directions of tourism development in the Odra Valley (pp. 215-226). Łódź: Wydawnictwo Łódzkiego Towarzystwa Naukowego. [in Polish]

9. Naumowicz, K. (1985). Tourism Potential and Tourist Regionalization of Poland. Warszawa: PWE. [in Polish]

10. Urząd Statystyczny. (2009). Lubelskie Voivodeship. Subregions, Poviats, Municipalities 2009. Lublin: US. [in Polish]
11. Kondracki, J. \& Richling A. (1994). Physico-geographical regions. In Atlas Rzeczpospolitej Polskiej. Warszawa: Wyd. Główny Geodeta Kraju. [in Polish]

12. Kaszewski, B.M. (2008). Climate. In S. Uziak \& R. Turski (Eds.), The natural environment of the Lublin region (pp. 75111). Lublin: Lubelskie Towarzystwo Naukowe. [in Polish]

13. GUS. (2002). General agriculture census. Warszawa: GUS. [in Polish]

14. Rogalewski, O. (1977). Tourist Infrastructure. Warszawa: Wydawnictwa Szkolne i Pedagogiczne. [in Polish]

15. Gołembski, G. (Ed.) (1999). Regional aspects of tourism development. Warszawa-Poznań: Wydawnictwo Naukowe PWN. [in Polish]

16. Sołowiej, D. (Ed.) (1992). Fundamentals of human environment assessment methodology. Poznań: Wydawnictwo UAM. [in Polish]

17. Wyrzykowski, J. (1986). Geographical conditions of recreational holiday tourism development in Poland. Acta Universitatis Wratislaviensis, 935, Studia Geographica, 44. [in Polish]

18. Krzymowska-Kostrowicka, A. (1997). Geoecology of Tourism and Recreation. Warszawa: Wydawnictwo Naukowe PWN. [in Polish]

19. Kozłowska-Szczęsna, T., Błażejczyk K. \& Krawczyk B. (1997). Bioclimatology of man. Methods and their application in the climate study in Poland. Warszawa: IGiPP PAN, Ser. Monografie l. Akapit-DTP. [in Polish]

20. Wyrzykowski, J. (1984). Optimal periods of tourist use of the recreational values of the Polish natural environment. Acta Universitatis Wratislaviensis B 656(5), 123-134. [in Polish]

21. Leśko, R. \& Mazurek Cz. (1977). The length of the climate bathing season for Polish rivers. Czasopismo Geograficzne 1, 11-22. [in Polish]

22. Lijewski, T., Mikułowski B. \& Wyrzykowski J. (2002). Polish tourism geography. Warszawa: Polskie Wydawnictwo Ekonomiczne. [in Polish]

23. Kozłowska-Szczęsna, T. (1991). Antropo-climate of Poland. Zeszyty Instytutu Geografii i Przestrzennego Zagospodarowania PAN 1, 1-265. [in Polish]

24. Błażejczyk, K. (2004). Bioclimatic conditions for tourism recreation in Poland. Prace Geograficzne 192, 1-291. [in Polish]

25. Kozłowska-Szczęsna, T. (2002). Bioclimate of the Polish Spas and Possibilities of its Use in Therapeutics. Warszawa: Monografie IG i PZ PAN, 3. [in Polish]

26. Wojewódzki Inspektorat Ochrony Środowiska. (2008). Report on the state of the environment of the Lubelskie Voivodeship. Lublin: Biblioteka Monitoringu Środowiska. [in Polish]

27. Wojciechowski, K.H. (1993). The attractiveness of the landscape as a component of the visual assets. In M. Pietrzak (Eds.), Landscape ecology in studies of territorial recreation systems (pp. 127-130). Poznań: Wydawnictwo KIBS. [in Polish]

28. Wyrzykowski, J. (Ed.) (1991). Assessment of the Polish Landscape in Physiognomic Terms for the Tourism Purposes. Wrocław: Wydawnictwo Uniwersytetu Wrocławskiego. [in Polish]

29. Bezkowska, G. (2003b). Problems of evaluation of natural assets for tourism and recreation in the area of the CentralPoland Lowlands. Turystyka i Hotelarstwo 4, 9-11. [in Polish]

30. Bezkowska, G. (2003a). The attractiveness of the natural environment for tourism and recreation. In S. Liszewski (Ed.), Possibilities and trends of tourism in the Odra valley (str. 63-73). Łódź: Wydawnictwo Łódzkiego Towarzystwa Naukowego. [in Polish] 
31. Hasse, G. (1978). Origin and characteristics of natural potential. Pettermanns Geographishe Mittelungen 122(2), 113125. [in German]

32. Tucki, A. (2009). Tourism potential of the region of Lublin and its possible uses. Doctoral thesis, Archiwum Biblioteki Głównej UMCS, Lublin. [in Polish]

Submitted: December 9, 2010

Accepted: February 15, 2011 